\title{
Extended ecosystem function analysis - the next step for mine rehabilitation appraisals
}

\author{
RN Humphries Blakemere Consultants Ltd, UK
}

\begin{abstract}
Ecosystem Function Analysis/Landscape Function Analysis (LFA/EFA) is a long established and well received science-based monitoring and assessment technique for rehabilitated mines sites in Australia. It provides keystone evidence for the re-establishment of ecosystem function in the form of soil condition across a range of mine substrates and climatic conditions.

LFA/EFA, in its current form is less concerned with subsequent ecosystem type and development in terms of vegetation composition and structural formation by which communities are recognised and characterised. Similarly, LFA/EFA is not concerned with their condition and, in particular, life-cycle states and dynamics which constitute the key foundation of sustainable ecosystems.

The purpose of this paper is to consider whether there is scope for extending the LFA/EFA methodology for assessing revegetation success and ecosystem sustainability. Having examined the methodology and the ability to integrate an index-based assessment of composition, structure and condition, it is concluded that the LFA/EFA methodology can be extended. Hence, it is recommended that the suggested modifications are considered further and developed as necessary to enhance the current LFA/EFA methodology and also to meet biodiversity enhancement expectations.
\end{abstract}

\section{Introduction}

The restoration of sustainable and functional ecosystems has been long advocated as the founding science-based principle for the successful rehabilitation of sites following major disturbance such as mineral extraction and waste disposal (eds Chadwick \& Goodman 1975; eds Holdgate \& Woodman 1978; ed. Wali 1979; Bradshaw \& Chadwick 1980). The principles have since been accepted and incorporated into Australian Federal and State legislation, policy and guidance regarding the permitting of mine schemes and certification of rehabilitation schemes for mine closure (e.g. Mulligan et al. 2006b; Department of Mines and Petroleum and the Environmental Protection Agency 2011; Department of Environment and Heritage Protection 2014). As a consequence, there is often a requirement to demonstrate that the process of re-establishment and sustainability are being or have been achieved.

Similar aspirations arose in the 1980s and 1990s owing to the widespread degradation of Australia's rangeland soils following over-exploitation. As a result of research by CSIRO's scientists (Tongway 2005), a repeatable and standardised methodology was devised to detect change (degradation, stability or enhancement) in a range of landscapes and land uses. It was called the Landscape Function Analysis (LFA). The LFA scores the soil condition and productivity in terms of eleven soil-surface variables representing soil surface stability, infiltration, and nutrient accumulation and cycling (Tongway \& Smith 1989; Tongway 1994; Ludwig \& Tongway 1992, 1995; Tongway \& Hindley 2000; Tongway n.d.(a)). Its application enabled rapid assessment and management actions and measures to address soil degradation. Coincidentally, it was realised that the LFA approach was applicable to rehabilitated mine sites given the initial degraded landscape and soils (Tongway et al. 1997).

Over the past 20 years the application of LFA and its index-based approach has been demonstrated to be applicable across different climates and mine rehabilitation schemes (Tongway \& Hindley 2003; Jasper et al. 2006; Haagner et al. 2008; Lacy et al. 2008; Maestre \& Puche 2009; Tongway \& Ludwig 2011; Pauw 2011; Mustapha 2013; Tongway n.d.(b)). The methodology is well-established in Australia and becoming so 
elsewhere. Consequently it is very familiar to those in both government and industry who are concerned with mine closure regulation and criteria (e.g. Randall 2004; Department for Manufacturing, Innovation, Trade, Resources and Energy 2013; DnA Environmental 2013, 2014; EBS Ecology 2013; Glencore 2014; Fortescue 2014).

Whilst in principle there is general acceptance of the methodology, both Tongway and Hindley (2003) and others (Erskine et al. 2013) have pointed out that, under some circumstances, the soil-based derived indices may not reflect the functional success of some rehabilitation schemes or that there may be concerns about adequate sampling. Here, careful application and interpretation is required. Notably, the focus of comment on the methodology has largely been on the reliability of the indexed soil-based component with less about the use of vegetation metrics beyond those for assessing soil function development - a point emphasised by Tongway (n.d.(a)).

In recognition of the overarching role of vegetation establishment and development in the rehabilitation of ecosystems on mine sites, parameters representing the vegetation structural element were added in the development of the methodology. This was referred to as the extended function analysis (Tongway n.d.(a), n.d.(b)) which has seemingly become synonymous with the later used term Ecosystem Function Analysis (EFA) (Tongway \& Hindley 2003). Also, it seems both the terms LFA and EFA have over time become interchangeable.

The purpose of this contribution to the application of LFA/EFA is to consider whether there is scope for extending the methodology to include the key vegetation plant-based ecosystem attributes of composition, structure and condition as the next step in mine rehabilitation appraisals.

\section{The LFA/EFA methodology}

Tongway and Ludwig (2006) and the South Australian Government's Department for Manufacturing, Innovation, Trade, Resources and Energy (2013) provide useful technical and data collection/handling introductions to the LFA/EFA methodology.

The LFA/EFA approach is a time-based methodology based on scoring a number of attributes for the landscape, soil and vegetation along a number of $100 \mathrm{~m}$ long transects orientated along the environmental gradient. By repeated sampling over a number of years, the attainment of sustainability is demonstrable as the stabilisation of the trajectory towards a range of target metrics measured for similar self-sustaining landscape-soil-vegetation analogues (Tongway \& Hindley 2003).

The landscape component (known as the Landscape Organisation Index (LOI)) is an indication of the ability of the rehabilitated area to facilitate the accumulation of resources such as plant litter, organic matter, nutrients and the consequential amelioration of the soil component. This is measured as the relative size of patches of vegetation along selected transects (Tongway n.d.(a), n.d.(b)), and scaled to 0-100 as essentially an estimate of ground cover. The LOI is generally reported separately from the other LFA/EFA components.

For the soil-based component, there are eleven soil-surface elements, including the basal cover of perennial vegetation as contributor to infiltration and nutrient cycling. The components of the LFA/EFA soil-surface assessment are listed below:

- Soil cover.

- Basal and canopy cover.

- Litter cover.

- Cryptogam cover.

- Crust broken-ness.

- Erosion features.

- Deposition materials. 
- Surface roughness.

- Surface resistance to disturbance.

- Slake test.

- Soil texture.

Each soil component is scored along each transect and integrated into the three soil surface indices (aggregated scores scaled to $0-100$ ) which are indicative of the three ecosystem functional conditions of soil stability, infiltration and nutrient cycling. Each of these three soil surface characteristics are usually reported separately.

The collection of vegetation data for the LFA/EFA is seemingly less systematic as it is considered that the functional role of the vegetation in resource accumulation and mobilisation is already integrated into both the LOI and soils-surface indices. Tongway (n.d.(a), n.d.(b)) emphasises that this aspect of the methodology is not part of the evaluation process, but merely indicative of environmental gradients such as wind or water. Consequently, the scope and detail of reporting of the vegetation component is expected to be less prescriptive and to vary between site circumstances, rehabilitation objectives and completion criteria, and assessor preferences (e.g. Mulligan et al. 2006a; DnA Environmental 2013; EBS Ecology 2013).

\section{The LFA/EFA vegetation composition and ecosystem components}

Despite the above, Tongway (n.d.(a), n.d.(b)) refers to the collection of data, as part of the LFA/EFA process, that represented the structural development of the vegetation along transects. This takes the form of density, cover and species composition being recorded as overall plant density, percentage vegetation cover, height to the canopy of grass tussocks, and/or shrub and tree canopies in $0.5 \mathrm{~m}$ height classes. Tongway and Hindley (2003) also refer to the collection of life-form data as an indication of structural composition and habitat complexity, to which native and exotic species diversity can be added. These data are also reported separately from the other components.

As the LFA/EFA methodology is primarily concerned with vegetation in its roles of water and nutrient resource accumulation and mobilisation, it does not inform about the type of vegetation in respect of composition, structure and renewal. This is an important omission as they are the prime indicators of ecosystem rehabilitation and sustainability (Humphries 2013b). In the examples cited and reported by Tongway (n.d.(b)), Lacy et al. (2008), DnA Environmental $(2013,2014)$ and EBS Ecology (2013), there is no requirement to characterise the developing vegetation community, structure and condition. While the soil surface may be nutrient rich, stable and have a high infiltration capacity, the vegetation present may not be a type that meets the rehabilitation and completion criteria objectives and/or may not be sustainable as has been pointed out for some forest rehabilitation schemes (Humphries 2016). For example, the sheoak (Alocasuarina) dominated stands on rehabilitated mineral sand mines in Queensland (Gravina et al. 2011) are likely to have scored highly in the LOI and the LFA/EFA methodology. Had other vegetation and ecosystem characteristics been collected whilst undertaking the LFA/EFA, and due weight given, the conclusion arrived at would have been different. Despite the apparent attainment of a stabilised ecosystem, the dense scrub structure was not the vegetation and ecosystem for the target regionally important native sand dune heath/forest described by Gravina et al. 2011, and Smith and Nichols 2011. It also exhibited no evidence or indication of community renewal for its future stability as a vegetation type (Humphries 2016). This situation is not unique to the mineral sand rehabilitation and is evident in rehabilitation elsewhere.

\section{$4 \quad$ Collection of additional relevant data}

Given the above, what would be useful and relevant vegetation data? Essentially there are three types of data: the species composition of the vegetation, the structural formation of that vegetation, and the condition of the vegetation. They are all used in the definition and assessment of ecosystem resources in Australia and elsewhere (Humphries 2014). These, together, could contribute more usefully in determining 
the achievement of the rehabilitation objectives and identification of necessary intervention or other measures, which were the principle purpose of the original LFA/EFA methodology set out by Tongway (2005).

Not only does the collection of this information enable a more cognisant interpretation of the progress and state of rehabilitated ecosystems on mine sites, it also can inform actions and measures that enable intervention and maintenance such as advocated by Gravina et al. (2011) and implemented by others (Grigg \& Grant 2009), and as recognised by Tongway and Ludwig (2011).

\subsection{Composition}

The composition of the establishing and developing vegetation is a very important descriptor of the ecosystem and forms the basis of whether the mine rehabilitation objectives and closure criteria are being achieved, and if they are likely to be sustainable. It tells us what sort of vegetation is present and enables an assessment against the target types in terms of desirable and undesirable species, and species richness. It helps to detect change and is indicative of measures needed to achieve sustainability.

The target vegetation might be recognisable native types for which there may be reference analogues or published accounts against which comparisons can be made (Humphries 2014). There are national descriptions for broad vegetation types (Department of the Environment and Water Resources 2007). Equally at a state level, Queensland for example, there are detailed vegetation descriptions for the ecosystems (Department of Science, Information Technology, Innovation and the Arts 2012) that can be used. In other circumstances, non-native species assemblages may be appropriate for which target lists can be constructed (Neldner \& Ngugi 2014). The same approach of creating a list of target species applies in the absence of analogues and written accounts for less familiar assemblages, such as those associated with post-mining substrates and wastes (Humphries \& Tibbett 2015).

Species composition also has a role in mine rehabilitation in identifying the occurrence of exotic species, including notifiable species, which may be dominant and/or persistent. For example, DnA Environmental (2013) report the non-native exotics (fireweed, Senecio madagascariensis; sowthistle, Sonchus oleraceus; cat's-ear, Hypochaeris radicata), and the notifiable prickly pear (Opuntia stricta), were amongst the most commonly occurring species in their transects, but no weight was given in the LFA/EFA nor the consequence for the ecosystem established.

Hence, site recording requires a list of species and their abundance. Currently, such data are not routinely collected as part of the LFA/EFA process, and where they are collected they are typically not being used to determine the type of vegetation ecosystems being assessed and to identify significant species and assemblages. Using this type of data it was possible to project the likely development trajectory of forest rehabilitation and achievement of the objectives and criteria at three mines (Humphries 2016). Given the establishment was not reflecting those of the target assemblages, such data would enable the identification of the need for changes in establishment practice and any necessary intervention to achieve the rehabilitation objectives, as described by Grigg and Grant (2009), Gravina et al. (2011), and Smith and Nichols (2011).

\subsection{Structural classification}

The structural formation of vegetation is also an important descriptor of the ecosystem, its development, and the regeneration and succession processes being assessed. It tells us, for example, whether the ecosystem is tree, shrub, herbaceous or cryptogam based, whether it is a closed or open system, and whether it is changing from one to another form. Using vegetation structural formation data it was possible to determine the current development trajectory of forest rehabilitation and achievement of the objectives and completion criteria at three mines, and enabled the identification of the critical need for intervention to achieve the rehabilitation objectives (Humphries 2016).

Eyre et al. (2011) have published a useful classification for vegetation structural formations that could be applied to determine the nature and development of establishment on mine sites. It is currently deployed in 
Queensland as part of its regional ecosystem descriptions and classifications, and has been advocated for forest ecosystems in Queensland and Western Australia (Humphries 2016).

The classification covers sparse-forbland to tall closed-forest structural formation types. The spectrum of formations is easily recognisable and applicable to mine site rehabilitation. The formations have their own ecology and ecosystem dynamics which are understood and can be interpreted for measures to be taken to achieve the objectives and sustainability. Should a particular formation be deemed unique to a mine site, there is no reason (provided the rules of the classification are followed) why it should not be added to the classification.

The site recording input that is required will comprise: recognition of dominant growth form (e.g. trees, shrubs, grassland), height class of tree and shrub species, and their canopy cover. From the matrix a structural formation class can be assigned. Currently, this data collection is not part of the LFA/EFA process.

\subsection{Condition}

Eyre et al. (2011) set out that condition monitoring is concerned with the functioning of ecosystems in relation to the maintenance of its biodiversity value which, as explained above, is not currently part of the LFA/EFA methodology. Whilst there is a long history in Australia of land condition for stock rearing, the attributes used were considered to be inadequate regarding biodiversity assets and as a result a range of other methodologies have been developed (Humphries 2014). Of these, Queensland's Bio-Condition (Eyre et al. 2011) is probably the most appropriate in the context of LFA/EFA, and the assessment of mine rehabilitation as advocated by Neldner and Ngugi (2014).

Eyre et al. (2011), in assessing the condition of Queensland's ecosystems, use eight condition attributes comprising: native species richness, tree canopy cover and height, shrub layer cover, native perennial herb cover, number of large trees, amount of large woody debris and litter cover. However, these attributes are either already embedded in the LFA/EFA process or are part of the above composition and structure components. In the UK there is a long established use of condition monitoring where the attributes of canopy cover, age-class, regeneration potential, genetic pool, local indicators and exotic/alien species are used (Humphries 2013b, 2014). Of these, age-class (life-cycle stage), regeneration potential and genetic pool are not replicated within the LFA/EFA methodology or in the proposed additional composition and structure components. They are also absent in Queensland's Bio-Condition methodology advocated by Neldner and Ngugi (2014).

The ability of the established vegetation to replace itself or to be replaced by other successive types is fundamental to the sustainability and condition of forest ecosystems (Grant et al. 2007; Humphries 2016). For example, the number of age-classes (seedling, sapling, pole, mature, decaying, dead) and regeneration potential (seed production, vegetative sprouting) for woodland/forest is informative about the sustainability of the rehabilitated ecosystem. The same principle applies to other types of vegetation and ecosystems (Humphries 2013b).

\section{Integration of vegetation- and ecosystem-based indices into the LFA/EFA methodology}

The current LFA/EFA methodology can accommodate vegetation attributes as extended data although it is not incorporated into the final index-based assessment. It is considered here that there is scope for the incorporation of species composition, vegetation structure and condition attributes, and their indexation, for the purpose of assessing ecosystem function and sustainability for rehabilitation and mine closure certification purposes.

The following is an illustration of a possible approach of how such a LFA/EFA indexation might be devised. The example uses the monitoring of grassland established on former agricultural land at South Grange Farm as off-set mitigation for the predicted impact of underground coal mining on internationally important alluvial grassland (Humphries et al. 1998; Carstairs 2007). The results of the establishment of the very 
locally occurring type of priority UK biodiversity grassland are given in Humphries et al. (2014). Another example using the same approach for other habitat types at a rehabilitated surface coal mine is given in Humphries (2014).

\subsection{Composition}

Species lists and their abundance would be collected for each transect and assigned frequency 'classes' (Rodwell 2006) to facilitate comparison and determination of plant community type. Assessment of the LFA/EFA ecosystem composition could be by categorisation of the constant, notable and/or other species diagnostics as considered appropriate. Table 1 sets out the time sequence data from Humphries et al. (2014) from which simple counts and indexation over a six year period since seeding were derived. The indexed benchmark could be the local analogue, a published account or a specifically concocted model (target) type as appropriate to the native or novel vegetation, and presented in the conventional LFA/EFA form as a graph or figure, or as a simple table (e.g. Table 1), and accompanied with explanations and notes as appropriate.

Table 1 Derived community and indicator species indexation for a re-established grassland ecosystem (source of data: Humphries et al. 2014)

\begin{tabular}{|c|c|c|c|c|c|c|}
\hline \multirow[t]{2}{*}{ Metric } & \multicolumn{5}{|c|}{ Sample year } & \multirow{2}{*}{$\begin{array}{c}\text { Ellerton Ings } \\
\text { - local } \\
\text { analogue }\end{array}$} \\
\hline & 2007 & 2008 & 2010 & 2011 & 2012 & \\
\hline \multicolumn{7}{|c|}{ Community constant species } \\
\hline Number of species & 2 & 3 & 4 & 5 & 3 & 5 \\
\hline $\begin{array}{l}\text { Constant species } \\
\text { index (\%) }\end{array}$ & 40 & 60 & 80 & 100 & 60 & 100 \\
\hline \multicolumn{7}{|c|}{ Notable and local species indicators } \\
\hline Number of species & 5 & 6 & 8 & 8 & 7 & 9 \\
\hline $\begin{array}{l}\text { Species indicator } \\
\text { index (\%) }\end{array}$ & 55 & 66 & 88 & 88 & 77 & 100 \\
\hline
\end{tabular}

How the indexation in Table 1 is interpreted in terms of acceptability would be down to the agreement of acceptable targets. In this example, from Humphries et al. (2014), whilst concluding a plant community basis of the target type had been established, the authors used the findings to justify further and targeted seed collection and introduction (as further intervention) to boost the number of constant and indicator species. The justification for this approach was that the objective in this case was to establish a grassland as near to the local analogue composition as possible (Carstairs 2007). Elsewhere, lower thresholds of acceptability have been agreed and adopted (Smith \& Nichols 2011).

\section{$5.2 \quad$ Structure}

The structural formation classes of Eyre et al. (2011) or other (if considered to be more appropriate) can be derived from the collected data and used to assign a class. Assessment of the achievement of target ecosystem (whether cryptogam, grassland, open-shrubland, tall closed-forest etc.) would be by simple comparison of the assigned class. Monitoring over time would demonstrate the dynamics of structural development of the vegetation, and the trajectory as successional replacement, stalling or reversion processes.

Using the previous grassland example, the initial vegetation would be assigned a growth form for the predominant layer and initial foliage cover, thus a derived formation class. LFA/EFA indexation would be according to the foliage cover categories (similar procedure to the allocation of soil surface characteristics) giving a LFA/EFA index of 10, 30, 70 or $100 \%$. At South Grange Farm the target growth form was a closed 
grassland. The ground cover of the sown grassland over the six year period increased rapidly from being sparse to being a closed-grassland (Table 2).

Table 2 Derived structural formation indexation for a re-established grassland ecosystem

\begin{tabular}{ccccccc}
\hline Metric & $\mathbf{2 0 0 7}$ & $\mathbf{2 0 0 8}$ & $\mathbf{2 0 1 0}$ & $\mathbf{2 0 1 1}$ & $\mathbf{2 0 1 2}$ & $\begin{array}{c}\text { Ellerton Ings } \\
\text { - local } \\
\text { analogue }\end{array}$ \\
\cline { 2 - 7 } & $\mathbf{2 0 0 7}$ & Grassland & $\begin{array}{c}\text { Closed } \\
\text { grassland }\end{array}$ & $\begin{array}{c}\text { Closed } \\
\text { grassland }\end{array}$ & $\begin{array}{c}\text { Closed } \\
\text { grassland }\end{array}$ & $\begin{array}{c}\text { Closed } \\
\text { grassland }\end{array}$ \\
\hline $\begin{array}{c}\text { Growth } \\
\text { form }\end{array}$ & $\begin{array}{c}\text { Sparse } \\
\text { grassland }\end{array}$ & 60 & 75 & 100 & 90 & 80 \\
\hline $\begin{array}{c}\text { Foliage } \\
\text { cover (\%) }\end{array}$ & $<10$ & 70 & 100 & 100 & 100 & 100 \\
\hline $\begin{array}{c}\text { Structural } \\
\text { index (\%) }\end{array}$ & 10 & 70 & & & & \\
\hline
\end{tabular}

Should the grassland or other ground cover growth form be a precursor for later types, such as forest, it would be expected there would be a subsequent change with time. For example, the grassland might become structurally a shrubland with the development of a shrub or tree cover, then later a low open-forest before being categorised as tall closed-forest with the closure of the tree canopy. Here, the same principle would apply to derive a LFA/EFA index, but in parallel with the growth form descriptor (Table 3).

Table 3 Derived structural formation indexation for a re-established forest ecosystem

\begin{tabular}{cccccc}
\hline Metric & \multicolumn{3}{c}{ Vegetation development over time } & $\begin{array}{c}\text { Forest } \\
\text { analogue }\end{array}$ \\
\hline $\begin{array}{c}\text { Growth } \\
\text { form }\end{array}$ & $\begin{array}{c}\text { Open } \\
\text { grassland }\end{array}$ & Shrubland & $\begin{array}{c}\text { Low open- } \\
\text { forest }\end{array}$ & $\begin{array}{c}\text { Tall open- } \\
\text { forest }\end{array}$ & $\begin{array}{c}\text { Tall closed- } \\
\text { forest }\end{array}$ \\
\hline $\begin{array}{c}\text { Foliage } \\
\text { cover (\%) }\end{array}$ & $<10$ & 20 & 40 & 70 & 80 \\
\hline $\begin{array}{c}\text { Structural } \\
\text { index (\%) }\end{array}$ & 10 & 30 & 70 & 70 & 100 \\
\hline
\end{tabular}

\subsection{Condition}

Vegetation condition, as age-classes (i.e. evidence for seedlings, immature plants, mature plants, mature and seed producing/vegetative spreading plants, decaying/dead plants) present, regeneration potential (flowering, seed production, suckering, other vegetative means of reproduction etc.) being exhibited, and provenance of the vegetation in the selected transects are of particular relevance to mine rehabilitated sites (Humphries 2013b, 2014). Assessment of ecosystem function using age-classes can be based on an assigned number of classes to be expected for sustainability of the target ecosystem type and its management/utilisation. Similarly, regeneration potential can be based on the expected yield/number for sustainability of the target ecosystem type and its management/utilisation. Where genetic provenance is of importance, the proportion of the local genetic pool can be set for assessment purposes.

For the lowland hay-meadow grassland example, two age-class condition criteria of mature (seed producing) plants as an average summer sward height $>10 \mathrm{~cm}$ and $<25 \%$ ground cover of dead plant (litter) material have been set by the Joint Nature Conservation Committee (2004). In this case, the LFA/EFA index would be category based with each constituting a proportion of the total index as determined for the soil-surface characteristics. Table 4 sets out the values for the age-class criteria for the sown grassland at South Grange Farm. 
Table 4 Derived age-class indexation for a re-established grassland ecosystem

\begin{tabular}{|c|c|c|c|c|c|c|}
\hline \multirow[t]{2}{*}{ Metric } & \multicolumn{5}{|c|}{ Sample year } & \multirow{2}{*}{$\begin{array}{c}\text { Ellerton Ings } \\
- \text { local } \\
\text { analogue }\end{array}$} \\
\hline & 2007 & 2008 & 2010 & 2011 & 2012 & \\
\hline \multicolumn{7}{|c|}{ Summer sward } \\
\hline Height (cm) & 5 & 35 & 50 & 45 & 60 & 55 \\
\hline $\begin{array}{l}\text { Mature plant } \\
\text { index (\%) }\end{array}$ & 9 & 63 & 90 & 81 & 109 & 100 \\
\hline $\begin{array}{l}\text { Plant litter } \\
\text { cover }\end{array}$ & 0 & 5 & 10 & 20 & 30 & 20 \\
\hline $\begin{array}{l}\text { Dead plant } \\
\text { index (\%) }\end{array}$ & 0 & 25 & 50 & 100 & 150 & 100 \\
\hline
\end{tabular}

Regeneration potential can be considered sufficiently represented in this case by the grassland age-class reaching maturity by way of its summer height indexation without further determination (Joint Nature Conservation Committee 2004).

Provenance (as the source of the genetic pool) can be of great importance where local populations need to be protected or enhanced. As a rule of thumb, the Joint Nature Conservation Committee (2004) suggested that more than $95 \%$ of the vegetation should be of local provenance. In the grassland example here, all of the seed introduced was collected from local grassland known not to have been affected by historical over-sowing of agriculturally bred species. Indexation could simply be an estimate of the proportion of the local provenance introduced.

\subsection{Indices and indexation}

The above approach might be developed further to formulate overall EFA/LFA-like indices, as set out in Table 5, and integrated within the LFA/EFA methodology as developed for the soil-surface components.

Table 5 Possible component indices for extended-LFA/EFA indexation

\begin{tabular}{cc}
\hline Component indices & Extended-LFA/EFA indexation \\
\hline $\begin{array}{c}\text { Percentage constant species + percentage } \\
\text { species indicators }\end{array}$ & Community composition index \\
\hline $\begin{array}{c}\text { Percentage structural formation } \\
\text { Percentage age-class + percentage } \\
\text { regeneration potential + percentage } \\
\text { provenance }\end{array}$ & Vegetation structural index \\
\hline
\end{tabular}

\section{Discussion}

As Lacy et al. (2008) point out, the site index-based LFA/EFA methodology is now a long established and well accepted methodology across the mining industry and its regulators in Australia. As a bio-geo-chemical based methodology, it is particularly appropriate where the mining activity has degraded the soil resources, where soils have been lost, where dependence is on raw geological deposits or processed mineral material for site rehabilitation, particularly in extreme conditions. Where soils have been recovered and reused, such as may be the case in the mining of some bauxite and mineral sands deposits, the LFA/EFA methodology is likely to be less relevant and in these cases where monitoring and assessment methodologies may be based solely on 
vegetation attributes (Koch 2007; Smith \& Nichols 2011), although others have used time and soil-based (but non-indexed) criteria (Spain et al 2006; Tibbett 2010).

Where the LFA/EFA and LOI are applied, it is capable of detecting vegetation and soil development and can be used as an indicator of ecosystem function and trajectory towards achieving sustainability. Whilst there may be possible constraints on the method's application in certain circumstances, such as the poor verification of soil index association with soil-based parameters (Tongway \& Hindley 2003; Erskine et al. 2013), and the impracticality of deploying sufficient transects to detect spatially distributed processes on a site scale (Erskine et al. 2013), these may be overcome or addressed within the existing methodology. There are other sampling aspects of LFA/EFA and its application and limitations that span from reliance on fix-point transects to large scale application, but these are outside the scope of this paper.

Since the formulation of the LFA/EFA approach in the 1990s, there has been a substantial change in the emphases and drivers for assessing rehabilitation success. They have moved from a focus on the ability to establish soil-based systems on mine rehabilitation (e.g. Humphries \& Rowell 1994) to one on community-based ecosystems following the advent of the International Convention on Biological Diversity (Humphries 2000, 2001, 2014). Australia also ratified the Convention (Australian Government 1999) and consequently the composition and condition of native vegetation and ecosystems is of importance (Eyre et al. 2011). It is important to realise that the intent and scope of the Convention goes beyond the protection and prescriptive replication of the pre-mining habitats and ecosystems, and embraces positive contributions, under provisions for enhancement, that restoration and rehabilitation schemes can bring to the overall global and local biodiversity capital. This also applies equally to the so-called novel ecosystems that are characteristic of some post-mining landscapes and substrates (Doley et al. 2012; Erskine \& Fletcher 2013; Humphries 2013a; Humphries \& Tibbett 2015). Clearly, vegetation community, structure and condition metrics are not the preserve of nature conservation prized assets, but are universal attributes of plant-based ecosystems. Given they are applicable to all non-cultivated/highly managed systems, e.g. forestry, agriculture, it would be a logical step to incorporate vegetation data collection and assessment into the LFA/EFA methodology. In this way the methodology would contribute to the drive for biodiversity enhancement following mining.

For the LFA/EFA to be a universal methodology it needs to be able to detect the ability of the ecosystem and its successors to replicate and replace successive generations as the basis for ecosystem rehabilitation and sustainability. Firstly, for practical and consistency reasons, it may be preferable that the LFA/EFA methodology is extended rather than having to undertake an addition procedure. Secondly, to this end, the South Grange Farm example sets out a possible extended structure and form of indexation that might enable integration into the LFA/EFA methodology. It is acknowledged that the indexation of the soil-surface components in the LFA/EFA methodology were subject to extensive verification (Tongway \& Hindley 2003; Tongway 2005). A similar process would be expected in the development of the proposed extended LFA/EFA methodology, along with a review and setting of appropriate attributes for target vegetation types.

The strengths of the LFA/EFA as a methodology are that it has been accepted as a cost-effective methodology for the mining industry and has been sufficiently robust to be accepted by regulators and others. A particular advantage of integration of the suggested extension to the methodology is the formalisation of vegetation parameters within the monitoring and assessment of rehabilitated sites, rather than them being discretionary and subject to an organisation's or individual's preference. Limitations of cost and adequately skilled resources are often said to be reasons why seemingly demanding vegetation monitoring is not routinely undertaken. As illustrated and discussed previously, there seems to be no reason why an extended LFA/EFA might not be as equally practical and cost-effective.

\section{Conclusion}

It is concluded that the current LFA/EFA methodology could be extended to include vegetation and plant based ecosystem attributes which would be assessed in concert and integrated with the current soil-based monitoring. It would not require significant additional mobilisation and the attributes to be recorded are 
likely to be relatively easy to recognise and score. The identification of the key plant community species and the other required plant attributes are unlikely to need a specialist with the production and publication of appropriate guidance. Hence, it is recommended that the suggested extension to the LFA/EFA methodology be considered further and developed as necessary to enhance the current methodology. It is also suggested that the methodology is referred to as the Extended-EFA Methodology to avoid confusion with the current LFA/EFA soil-based methodology and to reflect David Tongway's original thinking.

\section{Acknowledgement}

Harley Lacy of MWH kindly commented on early drafts of this paper which were of great help and encouragement.

\section{References}

Australian Government 1999, Environment Protection and Biodiversity Conservation Act 1999, viewed 17 August 2015, http://environment.gov.au/epbc/

Bradshaw, AD \& Chadwick, MJ 1980, The Restoration of Land: The ecology and reclamation of derelict and degraded land, Blackwell Scientific Publications, Oxford.

Carstairs, I 2007, The Yorkshire River Derwent: Moments in time, Halsgrove Discover Series, Wellington.

Chadwick, MJ \& Goodman, GT (eds) 1975, The Ecology of Resource Degradation and Renewal, Blackwell Scientific Publications, Oxford.

Department for Manufacturing, Innovation, Trade, Resources and Energy 2013, Minerals Regulatory Guidelines MG19: Guidelines for data entry and reporting of landscape function analysis, South Australian Government, Adelaide.

Department of Environment and Heritage Protection 2014, Guidance Resource Activities: Rehabilitation requirements for mining resource activities, Queensland Government, Brisbane.

Department of Mines and Petroleum and the Environmental Protection Agency 2011, Guidelines for Preparing Mine Closure Plans, Government of Western Australia, Perth.

Department of Science, Information Technology, Innovation and the Arts 2012, Regional ecosystem Technical Descriptions, viewed 15 August 2015, http://www.qld.gov.au/environment/plants-animals/plants/ecosystems/descriptions/

Department of the Environment and Water Resources 2007, Australia's native vegetation: a summary of Australia's major vegetation groups, Australian Government, Canberra.

DnA Environmental 2013, 2012 Ecological Monitoring Report - Bulga Coal Complex, Bulga Surface Operations Pty Ltd \& Bulga Underground Operations Pty Ltd.

DnA Environmental 2014, 2013 Rehabilitation Monitoring Report - Northparkes Mines, North Mining Limited.

Doley, D, Audet, P \& Mulligan, DR 2012, 'Examining the Australian context for post-mined land rehabilitation: reconciling a paradigm for the development of natural and novel ecosystems amongst post-disturbance landscapes', Agriculture, Ecosystems and Environment, vol. 163, pp. 85-93.

EBS Ecology 2013, Kanmantoo Mine LFA Monitoring - Autumn 2013, Hillgrove Resources.

Erskine, PD \& Fletcher, AT 2013, 'Novel ecosystems created by coal mines in central Queensland's Bowen Basin', Ecological Processes, vol. 2, p. 33.

Erskine, PD, Fletcher, AT \& Seaborn, B 2013, 'Opportunities and constraints of functional assessment of mined land rehabilitation', in M Tibbett, AB Fourie \& C Digby, Mine Closure 2013: Proceedings of the Eighth International Conference on Mine Closure, Eden Project, Cornwall, UK, Australian Centre for Geomechanics, Perth, pp. 345-354.

Eyre, TJ, Kelly, AL \& Neldner, VJ 2011, Method for the Establishment and Survey of Reference Sites for BioCondition. Version 2.0, Department of Environment and Resource Management, Biodiversity and Ecological Sciences Unit, Brisbane.

Fortescue 2014, Desktop Study of Rehabilitation Strategies in the Pilbara - Christmas Creek Approvals, Fortescue Mining Group.

Glencore 2014, BAAL BONE Underground: 2014 Biodiversity and Land Management Plan.

Grant, CD, Ward, SC \& Morley, SC 2007, 'Return of ecosystem function to restored bauxite mines in Western Australia', Restoration Ecology, vol. 15, 4 (supplement), pp. S94-S103.

Gravina, AJ, McKenna, P \& Glenn, V 2011, 'Evaluating the success of mineral sand mine rehabilitation on North Stradbroke Island, Queensland: comparisons with reference eucalypt communities', in AH Arthington, TJ Page, CW Rose \& S Raghu (eds), Proceedings of the Royal Society of Queensland: A Place of Sandhills: Ecology, Hydrogeomorphology and Management of Queensland's Dune Islands, vol. 117, Royal Society of Queensland, St Lucia, pp. 419-435.

Grigg, AH \& Grant, CD 2009, 'Overstorey growth responses to thinning, burning and fertiliser in 10-13-year-old rehabilitated jarrah (Eucalyptus marginate) forest after bauxite mining in south-western Australia', Australian Forestry, vol. 72, (2), pp. 80-86.

Haagner, ASH, Kellner, K \& Tongway, DJ 2008, 'Enhancing conventional rehabilitation monitoring in South Africa by adding landscape function characteristics,' in AB Fourie, M Tibbett, IM Weiersbye \& PJ Dye (eds), Third International Conference on Mine Closure, Australian Centre for Geomechanics, Perth, pp. 809-820.

Holdgate, MW \& Woodman MJ (eds) 1978, The Breakdown and Restoration of Ecosystems, Plenum Press, New York. Humphries, RN 2000, 'Biodiversity: Curse or Opportunity?', Mining Quarrying \& Recycling, vol. 29, (10), pp. $26-29$.

Humphries, RN 2001, 'Biodiversity: Approaches to diversity', Mining Quarrying \& Recycling, vol. 30, (1), pp. 33-37. 
Humphries, RN 2013a, 'Case Study: The contribution of active surface mines in the conservation of lichen communities in the South Wales Coalfield, United Kingdom', Journal American Society of Mining and Reclamation, vol. 2 (1), pp. 80-98.

Humphries, RN 2013b, 'Understanding and delivery of the components of structure, diversity, and function in the restoration of ecosystems on mined land: working towards a practical methodology', Journal American Society of Mining and Reclamation, vol. 2, (2), pp. 1-31.

Humphries, RN 2014, 'Why reinvent the wheel when there are established methodologies to aid the design and assessment of restored natural ecosystems on mined land?', in Life of Mine 2014 Conference, Australian Institute of Mining and Metallurgy, Carlton, Victoria, pp. 675-692.

Humphries, RN 2016, 'Some lessons from long term monitoring of forest rehabilitation at three surface mine complexes in Australia', Journal American Society of Mining and Reclamation, vol. 5, (1), in press.

Humphries, RN \& Rowell, TA 1994, The Establishment and Maintenance of Vegetation on Colliery Spoils, British Coal Corporation, Eastwood.

Humphries, RN \& Tibbett, M 2015, 'Does the concept of novel ecosystems have a place in mine closure and rehabilitation?', in AB Fourie, M Tibbett, KG Mercer \& D van Zyl (eds), Tenth International Conference on Mine Closure, Australian Centre for Geomechanics, Perth, p. 11.

Humphries, N, Lunn, J \& Benyon, P 2014, 'Establishment of meadow foxtail-great burnet meadows (MG4) on former pasture at South Grange Farm, in the East Riding of Yorkshire', The Naturalist, vol. 139, pp. 197-209.

Humphries, RN, Wessemann, H, Benyon, PR \& Peace, S 1998, 'Assessing the effects of mine subsidence on an internationally important wetland site', in D Throgmorton, J Nawrot, J Mead, J Galetovic \& W Joseph (eds), Proceedings of 15th Annual National Meeting of the American Society for Surface Mining \& Reclamation, St Louis, USA, p. 446.

Jasper, DA, Veneklaas, EJ, Nichol, OG \& Tongway, DJ 2006, 'Indicators of success in mine site restoration in tropical moist forest ecosystems,' in A Fourie \& M Tibbett (eds), Proceedings First International Seminar on Mine Closure, Australian Centre for Geomechanics, Perth, pp. 719-730.

Joint Nature Conservation Committee 2004, Common Standards Monitoring Guidance for Lowland Grasslands, viewed 15 August 2015, http://Joint Nature Conservation Committee.defra.gov.uk/PDF/CSM_lowland_grassland.pdf

Koch, JM 2007, 'Restoring a jarrah forest understorey vegetation after bauxite mining in Western Australia', Restoration Ecology, vol. 15, 4 (supplement), pp. S26-S39.

Lacy, HWB, File, T \& Biggs, B 2008, 'Ecosystem Function Analysis: Measuring and monitoring for mine closure and completion in Australia and abroad - 1994 to 2008', in AB Fourie, M Tibbett, IM Weiersbye \& PJ Dye (eds), Third International Conference on Mine Closure, Australian Centre for Geomechanics, Perth, p. 321-333.

Ludwig, JA \& Tongway, DJ 1992, 'Monitoring the condition of Australian arid lands: linked plant-soil indicators', in DH McKenzie, DE Hyatt and VJ McDonald (eds), Ecological Indicators, Elsevier Press, Essex, pp. 765-772.

Ludwig, JA \& Tongway, DJ 1995, 'Spatial organisation of landscapes and its function in semi-arid woodlands', Australian Landscape Ecology, vol. 10, pp. 51-63.

Maestre, FT \& Puche, MD 2009, 'Indices based on surface indicators predict soil functioning in Mediterranean semi-arid steppes', Applied Soil Ecology, vol. 41, pp. 342-350.

Mulligan, DR, Gillespie, MJ, Gravina, AJ \& Curry, NA 2006a, 'An Assessment of Direct Revegetation Strategy on the Tailings Storage Facility at Kidston Gold Mine, North Queensland, Australia', in AB Fourie \& M Tibbett (eds), Proceedings First International Seminar on Mine Closure, Australian Centre for Geomechanics, Perth, pp. 371-381.

Mulligan, DR, Scougall, J, Williams, DJ, Nichols, O, Tibbett M, Lindbeck K, Loch, R, Allan, J, Grun, W, Farrell, C \& Benbow, R 2006b, Leading Practice Sustainable Development for the Mining Industry: Mine Rehabilitation, Department of Industry Tourism and Resources, Canberra.

Mustapha, A 2013, Assessment of Rehabilitated Surface Mine Lands in Anglogold Ashanti, Obuasi. MSc Thesis, Kwame Nkrumah University of Science and Technology, Kumasi, Ghana.

Neldner, VJ \& Ngugi, M 2014, 'Application of the BioCondition assessment framework to mine rehabilitation', Ecological Management \& Restoration, vol. 15, 2, pp. 158-161.

Pauw, MJ 2011, Monitoring Ecological Rehabilitation on Coastal Mineral Sands in Namaqualand, South Africa, MSc Thesis, University of Stellenbosch, South Africa.

Randall, J 2004, 'Landscape Function Analysis: A tool for monitoring mine-site rehabilitation success', MESA Journal, vol. 35, pp. $24-27$.

Rodwell, JS 2006, National Vegetation Classification: user's handbook, Joint Nature Conservation Committee, Peterborough.

Smith, P \& Nichols, O 2011, 'Development and assessment of rehabilitation criteria for high dune mineral sands mining on North Stradbroke Island', in AH Arthington, TJ Page, CW Rose \& S Raghu (eds), Proceedings of the Royal Society of Queensland, A Place of Sandhills: Ecology, Hydrogeomorphology and Management of Queensland's Dune Islands, Royal Society of Queensland, St Lucia, vol. 117, pp. 347-363.

Spain, AV, Hinz, DA, Ludwig, JA, Tibbett, M \& Tongway, DJ 2006, 'Mine closure and ecosystem development - Alcan Gove Bauxite mine, Northern Territory, Australia', in A Fourie \& M Tibbett (eds), Proceedings First International Seminar on Mine Closure, Australian Centre for Geomechanics, Perth, pp. 299-308.

Tibbett, M 2010, 'Large-scale mine site restoration of Australian eucalypt forests after bauxite mining: soils management and ecosystem development', in Batty LC \& KB Hallberg, Ecology of Industrial Pollution, Cambridge University Press, pp. 309-326.

Tongway, DJ 1994, Rangeland Soil Condition Assessment Manual, CSIRO, Melbourne, pp. 309-326.

Tongway, D 2005, Ecosystem Function analysis: a discussion paper, viewed 13 August 2015, http://www.cse.csiro.au/research/ras/ efa/resources/LFAdiscussionpaper.pdf 
Tongway, D \& Hindley, N 2000, Landscape Function Analysis: Methods for monitoring and assessing landscapes, with special reference to mine sites and rangelands, CSIRO Sustainable Ecosystems, Canberra.

Tongway, D \& Hindley, N 2003, Indicators of Ecosystem Rehabilitation Success: Stage Two - Verification of EFA Indicators. Final Report for the Australian Centre for Mining Environmental Research, CSIRO Sustainable Ecosystems, Canberra.

Tongway, DJ \& Ludwig, JA 2006, 'Assessment of landscape function as an information source for mine closure,' in A Fourie \& M Tibbett (eds), Proceedings First International Seminar on Mine Closure, Australian Centre for Geomechanics, Perth, pp. 21-29.

Tongway, DJ \& Ludwig, JA 2011, Restoring Disturbed Landscapes: putting principles into practice, Island Press, Washington.

Tongway, DJ \& Smith, EL 1989, 'Soil surface features as indicators of rangeland site productivity', Australian Rangeland Journal, vol. 11, pp. 15-20.

Tongway, DJ, Hindley, NL, Ludwig, JA, Kearns, AJ \& Barnett, G 1997, 'Early indicators of ecosystem rehabilitation on selected minesites', in Demonstrating Environmental Excellence 97: Proceedings of the 22nd Annual Environmental Workshop, Adelaide, Minerals Council of Australia, Dickson.

Tongway, D n.d.(a), Landscape Function Analysis: the rapid assessment of soil health, viewed 13 August 2015, http://www.cse.csiro.au/research/ras/efa/resources/EFA_Overview_Ecol.pdf

Tongway, D n.d.(b), The LFA Monitoring Procedure: a monitoring procedure to assess mine site rehabilitation success, viewed 13 August 2015, http://www.cse.csiro.au/research/ras/efa/resources/EFA_Overview_Minesite.pdf

Wali, MK (ed.) 1979, Ecology and Coal Resource Development: 2 Volumes, Pergamon Press, New York. 